\title{
THE DEVELOPMENT OF LEARNING MODEL BASED ON PHILOSOPHICAL VALUES OF ATOIN METO TATTOO THROUGH VALUE CLARIFICATION TECHNIQUE (VCT) AND JIGSAW TO IMPROVE CULTURAL CONSCIOUSNESS IN THE STUDENTS OF SMA NEGERI 1 MOLLO SELATAN
}

\author{
Stevridan Yantus Neolaka ${ }^{1}$, Mulyoto $^{2}$, Akhmad Arif Musadad $^{3}$ \\ stevridanneolaka@gmail.com ${ }^{1}$ \\ Universitas Sebelas Maret, Indonesia ${ }^{1,2,3}$
}

\begin{abstract}
This study aims to obtain a values-based learning model history - philosophical tattoo Atoin Meto to raise awareness of the local culture of the students, using the approach to research and development (R \& D) with Jigsaw strategies and approaches that can be used values clarification in history. It consists of three phases namely the introduction, development, and testing. Preliminary study include literature studies and field studies (literature includes theories, concepts, relevant research results. The field study covering the curriculum, teachers, schools, infrastructure characteristics of the students). The technique of collecting data through questionnaires, observation, interviews, documentation and testing. Analysis of the data used is descriptive analysis, feasibility analysis model based on ratings validator. From the results of expert assessment of the material by $90 \%$ "good" category, expert models by $85 \%$ "good" category, a linguist at $100 \%$, the category of "very good", an instrument by $85 \%$ "good" category. Based on an assessment conducted by a team of experts concluded that the learning model has met the eligibility criteria so that it can be used in the process of teaching history.
\end{abstract}

Keyword: Value Clarification Technique; Atoin Meto Tatoo; Cultural Consciousness.

\section{INTRODUCTION}

The problems experienced in the world of education today is so complex one that is more advanced civilization of the world make the education system changes, too many adopt the system from the outside and forget the wisdom and values - noble values contained in the culture of each region slowly forgotten and not loaded in the classroom. Learning history is now the spearhead in shaping the character of the students to inculcate the value - the value of its culture so it can respond to the challenges in the era of globalization. But the reality is not yet present a historical study based learning local culture so the effect on the students 'attitudes towards students' awareness of culture in those areas is very low.

Results of research conducted by Iin Wariin Bashari (2013) in the Journal of Science Education. Economy Volume 1 No. 2 pages 112-118, to show the importance of 
local culture in an effort to instill and uphold the identity of the nation and the State in order to remain embedded among the younger generation of Indonesia. Thus the national education will contribute adequately to the formation of Indonesian human cultured, dignified, civilized and all Indonesian identity.

In general the model interpreted as an object or a concept that is used to represent something, something real, and convert or to change a form that is more comprehensive (Meyer, WJ in Trianto 2009: 21). Furthermore, according to Joyce \& Weil (in Rusman 2012: 133) The learning model is a plan or pattern can be used for curriculum (long term plan), designing materials - learning materials, guiding learning in the classroom. Before determining the learning model that will be used in learning activities there are a few things you should consider that the objectives to be achieved, materials and teaching materials, consideration of the student's perspective (Rusman 2012: 135).

Senior High School is the formal education that aims to support the achievement of national education, the intellectual life of the nation and develop fully human Indonesia. The subject of history is one of the subjects in high school who often emphasizes the character formation of students, and therefore required innovative instructional strategies as well as attractive combined with the local culture.

East Nusa Tenggara province, more specifically in the village Kusi Kuanfatu District of South Central Timor, have a culture inherited from ancestors. The culture believed and implemented by the community. One culture is a culture of tattoos. Tattoo culture is drawing on the skin with a sharp instrument such as a needle or rattan thorns, then the drawn body parts given dye, on leave to dry and form a permanent image on the body. This activity is done through a ritual process that must be followed by the entire community.

Embodiment tattoos produce artwork that has meaning and purpose. There are two motives Tattoos on the village community Kusi Kuanfatu District of South Central Timor, the crocodile motives (believed to be the ancestors) and the woven motives (as a sacrifice). Tattoo culture at the community level have values as follows :, philosophy of cooperation, ethical, religious, Value Unity, as a form of fish fraternity fellow villagers of Kusi Kuanfatu District of South Central Timor.

Not denying that history education has a very important function in shaping the national character, the quality of Indonesian human beings and society in general. Presumably this statement is no exaggeration, but until now still questionable success, in view of the phenomena of life Indonesia nation, especially the younger generation increasingly doubtful existence. With this fact means that there is something that must be addressed in the implementation of educational history (Alfian, 2007: 1).

It should be through education culture of a region have a place in the learning process so much more to explore and introduce the local culture or local wisdom to the 
younger generation so that the value - the value contained in the local culture or local knowledge to enhance understanding of the local culture as the cultural identity of the region.

Therefore, this study will develop a value-based model of teaching history philosophical tattoo Atoin Meto an effort to raise awareness of local culture on the subjects of history students at Senior High School 1 South Molo. The problem in this study is whether the history of the learning model based on value - value of tattoos Atoin Meto philosophical development results met the criteria and eligible for use in the teaching of history ?. The purpose of this study was to obtain a values-based learning model history philosophical tattoo Atoin Meto who have met the eligibility criteria so that it can be used in the teaching of history.

\section{RESEARCH METHODS}

Research type used in this research is the development, the more we know the term Research \& Development (R \& D). Definition of research and development by 1983 Borg \& Gall is a process used to develop and validate a product of education (in Punarji Setyosari, 2015: 276).

Based on the opinion of the above it can be concluded that the development of research aims to develop the knowledge, existing educational theories, or produce a product in the field of education and also to develop and validate the research products. Research development of an effort to produce a product or renew an existing product, which can be a medium of learning, learning model, and teaching materials. In this study will discuss the history of the learning model based on value - value of tattoosphilosophy Atoin Meto through a combined model of VCT and Jigsaw to raise awareness of local culture.

Referring to the concept of Brog and Gall, for the purposes of this study, then step a step in the model development process is simplified in accordance with the objectives to be achieved by the researchers. In the development of a value-based model of teaching history - philosophical tattoo Atoin Meto then the development of this model adopts the ADDIE instructional design model that includes the step (1) needs analysis phase; (2) product design / model; (3) development of a model; (4) the implementation of the model; (5) evaluation.

Of the five stages of the development of the above, it can be simplified into three stages: (1) the preliminary study; (2) development of a model; (3) test the effectiveness of the learning model. To develop a model of teaching history based on value - the value of philosophical tattoo Atoin Meto in this study the researchers used a model ADDIE which will start from the analysis of learning needs in developing learning models and materials used in this study at Senior High School 1 South Molo to stage revision and evaluation models as raising awareness of local culture. The purpose of this research to develop a 
value-based model of teaching history - philosophical tattoo Atoin Meto the research subject in class X State Senior High School 1 South Molo.

The study begins with a preliminary study to determine the problems and needs of teachers and students. In this preliminary study researchers to study literature and empirical studies, data collection techniques in this preliminary study include observation, interviews, questionnaires and documentation.

The results and information obtained as a basis for developing a model of teaching history. Design models that have been developed further validated by a team of experts that includes expert models, materials experts, linguists, and experts instrument. Further data analysis technique used is descriptive qualitative analysis of observations and interviews, then using quantitative descriptive analysis of the results of questionnaires for data processing and validation by a team of experts.

\section{DISCUSSION}

\section{Preliminary Study}

This preliminary study conducted with a view to find out the existing problems in the field so from the existing problems, the researchers could determine the needs of teachers and learners, the material to be taught and competencies expected to be achieved by learners. This preliminary study using qualitative descriptive approach, which has three core activities namely: literature review, observation, and data processing of the preliminary study.

A literature study is the first step in this research. A discussion based on reference books which have links with the local tradition based on history teaching, aims to strengthen the discussion material relating to the issues raised. In this study, analysis of literature meant the theoretical foundation for the development of models and related to history teaching based on philosophical valuestattoos, Atoin Meto and will be aligned with the Standards of Competence and Basic Competence at SMA Negeri 1 South Molo. In addition, the object of study of the local culture Atoin Meto tattoo can be used as a reference for teaching history which aims to raise awareness of local culture in the selflearners.

The activities conducted by researchers in the field study is to collect data and information in the field relating to the teaching of history that took place at Senior High School 1 South Molo during this time, and to know the attitude of the students towards the local culture through interviews to teachers and learners, observing learning resources, media, learning styles and characteristics of learners. This activity aims for consideration in developing a learning model that will be used.

Considering the result of preliminary study conducted by the author, the history teachers agree to collaborate in developing prior design of historical learning model based on philosophical values of atoin meto tattoo to improve the local cultural consciousness developed in learning syntax below: 
Syntax of Historical Learning Based on Philosophical Values of Atoin Meto Tattoo

1) Phase I of Jigsaw: in this stage, teacher conveys the objective and motivates the students corresponding to Standard Competency and Basic Competency. Teacher conveys the learning objective, the material to be studied, and learning model to be used with Jigsaw type of cooperative strategy.

2) Phase II of Jigsaw and Phase 1 of VCT: Conveying and Presenting Information. Teacher explains briefly the material to be studies, namely philosophical values of Atoin Meto tattoo and the strategy used in the learning. In this phase, teacher directs the students to find values contained in Atoin meto tattoo motif and teachers ask some questions to the students in order to measure the students' understanding on the material studied.

3) Phase III of Jigsaw and Phase II of VCT: Organizing group. Teacher creates a learning group with 6-7 students. Every group is given different assignment. In this phase, teacher assigns the students to search for information relevant to the material with a variety of learning sources such as book, article and internet. The result of group work is presented before the class.

4) Phase IV of Jigsaw: Guiding the learning group. In this phase, teacher serves to guide the learning group when its members find difficulty in completing the assignment, and gives recommendation regarding the paper assignment given in order to work on the paper jointly so that all members participate in this work.

5) Phase V of Jigsaw and Phase III of VCT: Evaluation and Reflection on discussion result. In this phase, teacher evaluates the result of group discussion conducted by means of presenting the result of group discussion before the class. It is expected that the presentation of group’s work can establish good cooperation between groups and create concord during the learning process.

6) Phase VI of Jigsaw: Conclusion (appreciating and reinforcing). In this phase, teacher along with students draw a conclusion related to the material studied, and 
appreciates and reinforces the group or individuals expressing opinion bravely and gives the group the input.

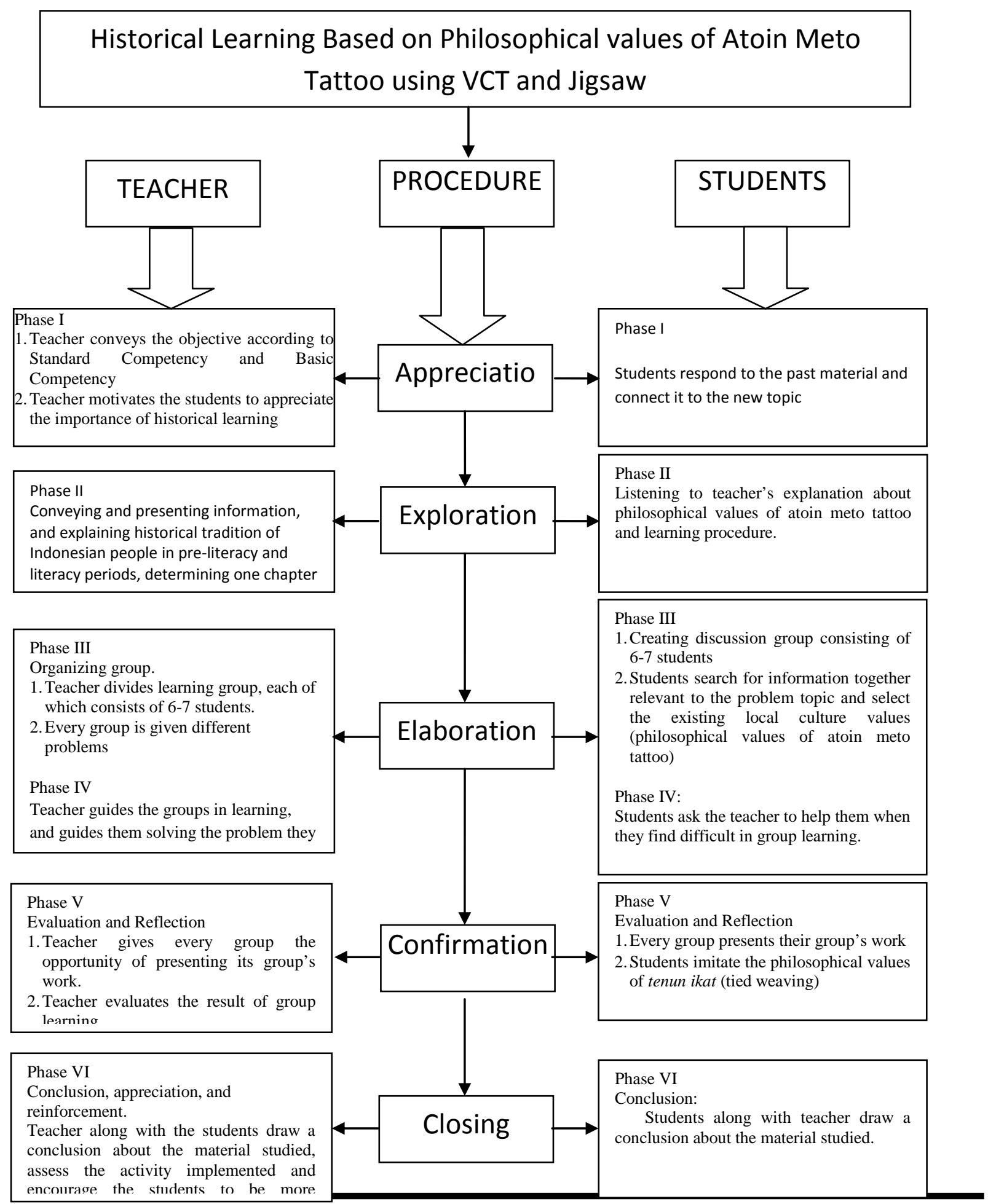

encourage the stiudents to he more 


\section{Design Philosophy Based Learning Model Tattoos Atoin Meto}

\section{Syntax of Historical Learning Model Based on Philosophical values of Atoin Meto Tattoo}

Structure

First phase $\quad$ : Conveying the learning objective according to Standard Competency and Basic Competency.

Second Phase $\quad$ : Delivering information on the material to be studied

Third Phase $\quad$ : Organizing learning group

Fourth Phase : Guiding the group

Fifth Phase $\quad$ : Evaluation and Reflection on discussion result

Sixth Phase $\quad$ : Drawing a conclusion, appreciating and reinforcing

\section{Social System}

Social system prevailing in this learning model is cooperative in nature, in which teacher becomes facilitator, motivation, and implements his/her learning democratically. This model is expected to make the students participate actively in the learning, thereby improving the students' learning outcome.

\section{Reaction Principle}

The principle of learning management implemented by teacher is to facilitate the students learn and as facilitator and consultant in learning group, teacher provides learning source and media related to learning model developed. Teacher guides the students in conducting analysis on the values consistent with the material discussed.

\section{Supporting System}

Supporting media in this learning model include: (1) implementation plan consisting of learning procedure, learning source and learning media; (2) group worksheet; (3) evaluation sheet serving to measure the student's mastery of competency and students' local cultural consciousness scale.

\section{Secondary effect}

Through the historical learning model based on philosophical values of atoin meto tattoo, the students are expected to have critical and creative thinking ability, be responsible, and to appreciate dissenting opinion and to cooperate.

\section{Syntax of learning model}




\section{Product Design Validation}

1. Material Expert Validation

\begin{tabular}{|c|c|c|c|c|c|c|}
\hline No & Aspect of & $\sum_{\mathbf{n}_{\mathbf{i}}}$ & $\sum$ & $\begin{array}{l}\mathrm{N} \\
\%\end{array}$ & Value & Criteria \\
\hline 1 & Contents & 46 & 52 & $100 \%$ & $88.46 \%$ & Very Good \\
\hline 2 & Presentation & 28 & 32 & $100 \%$ & $87.5 \%$ & Very Good \\
\hline 3 & $\begin{array}{l}\text { Assessment of } \\
\text { Learning }\end{array}$ & 8 & 8 & $100 \%$ & $100 \%$ & Very Good \\
\hline 4 & $\begin{array}{l}\text { The learning } \\
\text { approach }\end{array}$ & 16 & 16 & $100 \%$ & $100 \%$ & Very Good \\
\hline 5 & Evaluation process & 10 & 12 & $100 \%$ & $83.33 \%$ & Very Good \\
\hline & Score & 108 & 120 & $100 \%$ & $90 \%$ & Very Good \\
\hline
\end{tabular}

Aspects in value include: Content, Presentation, Learning Assessment Learning Approach, process evaluation. From the results of expert assessment of the material obtained a percentage of $90 \%$ so that the learning materials are classified in the category of "Very Good" and unfit for use

2. Model Validation Expert

\begin{tabular}{|c|c|c|c|c|c|c|}
\hline No & Aspect of & $\sum_{\mathbf{n}_{\mathbf{i}}}$ & $\sum$ & $\begin{array}{l}\mathbf{N} \\
\%\end{array}$ & Value & Criteria \\
\hline 1 & Display & 31 & 36 & $100 \%$ & $86.11 \%$ & Very Good \\
\hline 2 & Presentation & 54 & 64 & $100 \%$ & $84.73 \%$ & Very Good \\
\hline & Score & 85 & 100 & $100 \%$ & $85 \%$ & Very Good \\
\hline
\end{tabular}

Aspects in value include: materials, construction, and language. From the results of expert assessment of the model obtain a percentage of $85 \%$ sehingg learning model is classified in the category of "Very Good" and deserves to be tested.

3. Validation Linguists

\begin{tabular}{|l|l|l|l|l|l|l|}
\hline No & Aspect of & $\begin{array}{l}\sum \\
\mathbf{n}_{\mathbf{i}}\end{array}$ & $\sum$ & $\begin{array}{c}\mathbf{N} \\
\mathbf{\%}\end{array}$ & Value & Criteria \\
\hline 1 & $\begin{array}{l}\text { Qualifications } \\
\text { Language }\end{array}$ & 40 & 40 & $100 \%$ & $100 \%$ & Very Good \\
\hline \multicolumn{2}{|c|}{ Score } & 40 & 40 & $100 \%$ & $100 \%$ & Very Good \\
\hline
\end{tabular}


Targeted assessment Linguists get a percentage of 100\% up grouped in the category of "Very Good" and eligible for tested and can be used in the process of learning history.

4. Expert Validation Instrument

\begin{tabular}{|l|l|c|c|c|c|c|}
\hline No & \multicolumn{1}{|c|}{ Aspect of } & $\begin{array}{l}\sum \\
\mathbf{n}_{\mathbf{i}}\end{array}$ & $\sum$ & $\begin{array}{c}\mathbf{N} \\
\mathbf{\%}\end{array}$ & Value & Criteria \\
\hline 1 & Qualifications & 31 & 36 & $100 \%$ & $86.11 \% \%$ & Very Good \\
\hline 2 & Language & 54 & 64 & $100 \%$ & $84.37 \%$ & Very Good \\
\hline & Score & 85 & 100 & $100 \%$ & $85 \%$ & Very Good \\
\hline
\end{tabular}

Aspects in value include: manual, coverage, and language. From the results of expert assessment of the percentage of $85 \%$ thus obtained is classified in the category of "Good" and unfit for use.

\section{CONCLUSION}

Based on the results of research and discussion and assessment of a team of experts, we conclude that the history of the learning model based on value - the value of philosophical tattoo Atoin meto, has been declared fit to either category so that it can be used in the teaching of history. It is based on an expert assessment of the material by $90 \%$, 85\% Model expert, linguist $100 \%$ and $85 \%$ skilled instrument so that the learning model developed meets the eligibility criteria so that it can be used in the process pembelajara history.

\section{REFERENCES}

Alfian, Magdalia, dkk. 2007. Sejarah Untuk SMA dan MA Kelas XI Program Ilmu Pengetahuan Alam. Jakarta: PT. Gelora Aksara Pratama.

Iin Wariin Basyari, 2013. Jurnal Pend Ekonomi.Vol.1.No.2.Menanamkan Identitas Kebangsaan Melalui Pendidikan Berbasis Nilai - nilai Budaya Local.

Leo Agung dan Sri Wahyuni. 2013. Perencanaan Pembelajaran Sejarah. Yogyakarta: Ombak.

Martanto, SD, dkk. 2009. Pembelajaran Sejarah Berbasis Realitas Sosial Kontemporer Untuk Meningkatkan Minat Belajar Siswa. Semarang: Tidak Dipublikasikan.

Punarji Setyosari. 2015. Metode Penelitian Pendidikan \& Pengembangan. Jakarta: Prenadamedia Grup.

Rusman. 2012. Model-Model Pembelajaran Mengembangkan Profesionalisme Guru. Jakarta: PT Raja Grafindo Persada: Jakarta 
Triato. 2014. Mendesain Model Pembelajaran Inovatif Progresif dan Kontekstual: Konsep,landasan, dan implementasinya pada kurikulum 2013(kurikulum tematik integrative. KTI).Kencana Prenada Media:Jakarta 